Wojciech PIASECKI

Parasitology

\title{
CRUSTACEAN PARASITES FROM THREE FISH SPECIES FROM THE ODRA RIVER ESTUARY, POLAND
}

\section{PASOŻYTNICZE SKORUPIAKI TRZECH GATUNKÓW RYB Z WÓD UJŚCIOWYCH RZEKI ODRY, POLSKA}

\author{
University of Agriculture in Szczecin, Poland
}

\begin{abstract}
Three common, commercially important, freshwater fishes were surveyed for their crustacean parasites. A total of 387 roach, Rutilus rutilus, and a total of 370 bream, Abramis brama, were examined from 1985 to 1988 . The former carried three parasite species; the latter carried four. In addition a total of 433 pikeperch, Stizostedion lucioperca, was examined during 1984-1988. This fish species hosted four parasite species. Prevalence, intensity (range \& mean), and abundance were calculated for each parasite. Attention has been given to seasonal differences in infection, as well as to differences between the three localities sampled.
\end{abstract}

\section{INTRODUCTION}

Crustacean parasites of the three species of fresh-water fishes from the Odra River estuary were surveyed during 1985-1988. The host species were: roach, Rutilus rutilus (L.), bream, Abramis brama (L.), and pike-perch, Stizostedion lucioperca (L.). The work on the latter species was initiated in the fall of 1984. The fishes were sampled in three different areas, and at different times of the year. Preliminary results of the present study were included in unpublished surveys of the parasitic fauna of the three host fishes, prepared as internal reports contracted by the authorities of Szczecin District (Chodyniecki et al., 1985; Piasecki, 1989; Wierzbicka \& Piasecki, 1987).

The fishes mentioned above are relatively common commercially important finfish in the area as well as in central Europe. They differ essentially with respect to their ecology, food, and feeding habits. Both roach and bream are members of the family Cyprinidae, while pike-perch belongs to the family Percidae. Adult roach are 
small (21-38 $\mathrm{cm}$ total length), pelagic and feed mainly on plankton. Bream, on the other hand, are longer (32-55 cm total length), benthic and feed off the bottom. Pike-perch are even larger (37-77 $\mathrm{cm}$ total length), are found throughout the water column and are mainly piscivorious.

The Odra River estuary is more than $100 \mathrm{~km}$ long. It starts near the town of Widuchowa where the river bifurcates, forming two, parallel branches which are equal in size and which are interconnected with several canals. The eastern branch eventually forms the shallow, big Dąbie Lake, already in the limits of Szczecin City. The waters of the two branches of the river finally reunite in the narrow, short Domiazza passage. This expands into the Odra River Mouth (Roztoka Odrzanska), and ultimately becomes the Szczecin Lagoon (Zalew Szczecinski), which is separated from the Baltic Sea by two large islands: Wolin and Uznam. The Odra River Mouth is separated from the lagoon by Cheiminek Island. The river mouth is under the influence of sewage flowing directly from large nitrogen fertilizer plants in Police town (Zakłady Chemiczne "Police") and under indirect impact of Szczecin's communal and industrial waste waters, which are discharged to the Odra River. Dąbie Lake is relatively less contaminated than the river mouth and the lagoon. The latter water body ultimately collects the whole contamination load, because of limited communication with the open sea.

The crustacean parasites of the roach, bream, and pike-perch from the Odra river estuary were previously studied by Kozikowska (1957). In addition bream. parasites were surveyed by Wierzbicka (1978) on extensive material collected over three years.

\section{MATERIAL AND METHODS}

Fishes were collected in the spring, summer, and fall of each consecutive year (1985-1988 inclusive). Each fish species was sampled from the three localities of the Odra River estuary: the lagoon, the river mouth, and the lake. The first sample of the pike-perch was taken in the fall of 1984. Between 10 and 30 fish of each species were studied in each season of each particular year giving totals of 387 roach, 370 bream, and 433 pike-perch. Their dimensions (total length) and masses are given in Table 1.

The skin, fins, operculum, mouth cavity, branchial cavity, and gills were examined for the possible presence of crustacean parasites. The organs mentioned, except for the skin, were examined using a dissecting MBS microscope. The parasites found were identified under a Carl Zeiss compound miscroscope at magnifications up to $400 x$. Prevalence, intensity (range \& mean), and abundance of each parasite species were calculated for each fish species, for each season, and in each area studied. 
Table 1

Dimensions and masses of fishes studied

\begin{tabular}{l|c|c|c|c|c|c}
\hline \multirow{2}{*}{ Species \& year } & \multicolumn{3}{c|}{ Total length (cm) } & \multicolumn{3}{c}{ Mass (g) } \\
\cline { 2 - 6 } & min. & max. & mean & min. & max。 & mean \\
\hline 1984 & & & & & & \\
pike-perch & 39 & 72 & 52 & 490 & 3200 & 1276 \\
1985 & & & & & & \\
roach & 21 & 33 & 22 & 130 & 470 & 233 \\
bream & 32 & 53 & 40 & 490 & 2000 & 851 \\
pike-perch & 38 & 77 & 49 & 470 & 4820 & 1199 \\
1986 & & & & & & \\
roach & 23 & 36 & 28 & 130 & 600 & 278 \\
bream & 33 & 50 & 42 & 460 & 1750 & 914 \\
pike-perch & 37 & 65 & 50 & 460 & 2300 & 1135 \\
1987 & & & & & & \\
roach & 23 & 38 & 27 & 150 & 700 & 270 \\
bream & 34 & 55 & 40 & 600 & 3200 & 790 \\
pike-perch & 37 & 69 & 49 & 480 & 4100 & 1194 \\
1988 & & & & & & \\
roach & 23 & 38 & 28 & 130 & 520 & 278 \\
bream & 35 & 51 & 42 & 470 & 1700 & 974 \\
pike-perch & 39 & 72 & 48 & 450 & 3310 & 987 \\
& & & & & & \\
\hline
\end{tabular}

\section{RESULTS}

A total of 9988 individuals of five species of crustacean parasites was recovered from $1190^{\circ}$ fishes representing the three host species. Three parasites were common for all three host species; of the other two parasite species, one was found only in bream and the other only on pike-perch. Relevant infection details are given below:

Crustacean parasites of roach (Rutilus rutilus): (Table 2)

Ergasilus sieboldi von Nordmann, 1832 (Copepoda, Poécilostomatoida, Ergasilidae)

A total of 254 individuals was recovered from the 387 hosts studied. They occurred each year; in every season studied, and in all three localities. The overall prevalence (for the whole survey) was: $22.2 \%$, but it varied from $13.3 \%$ in 1985 to $29.2 \%$ in 1986 . The prevalence in the springs was low (12.8\%) increasing in the falls (35\%). E. sieboldi was less prevalent in the lake (14\%) than in the river mouth (26.4\%). The widest intensity range was 1-41 (1985, and the falls). The narrowest intensity range was 1-5 (1987 and the springs). The greatest intensities occurred in the lagoon (1-41); the lowest 
Table 2

Parameters of infection of roach, within 1985-1988

\begin{tabular}{|c|c|c|c|c|c|c|c|c|c|c|c|c|}
\hline Parasite species & $\begin{array}{l}\text { Invasion } \\
\text { para- } \\
\text { meters }\end{array}$ & 1985 & 1986 & 1987 & 1988 & Spring & Summer & Fall & Lagoon & $\begin{array}{l}\text { River } \\
\text { mouth }\end{array}$ & Lake & Overal * \\
\hline Ergasilus sieboldi & $\begin{array}{l}\text { PR } \\
\text { IR } \\
A B \\
M I\end{array}$ & $\begin{array}{l}13.3 \\
1-41 \\
0.56 \\
4.19\end{array}$ & $\begin{array}{l}29.2 \\
1-10 \\
0.82 \\
2.81\end{array}$ & $\begin{array}{l}22.2 \\
1-5 \\
0.36 \\
1.6\end{array}$ & $\begin{array}{l}27.4 \\
1-17 \\
0.93 \\
3.42\end{array}$ & $\begin{array}{l}12.8 \\
1-5 \\
0.16 \\
1.26\end{array}$ & $\begin{array}{l}21.2 \\
1-17 \\
0.75 \\
3.52\end{array}$ & $\begin{array}{l}35.0 \\
1-41 \\
1.18 \\
3.38\end{array}$ & $\begin{array}{l}26.1 \\
1-41 \\
0.98 \\
3.74\end{array}$ & $\begin{array}{l}26.4 \\
1-16 \\
0.6 \\
2.29\end{array}$ & $\begin{array}{l}14.0 \\
1-16 \\
0.38 \\
2.72\end{array}$ & $\begin{array}{l}22.2 \\
1-41 \\
0.67 \\
2.95\end{array}$ \\
\hline Caligus lacustris & $\begin{array}{l}\mathrm{PR} \\
\mathrm{IR} \\
\mathrm{AB} \\
\mathrm{MI}\end{array}$ & 0 & 0 & $\ldots$ & $\begin{array}{l}2.3 \\
1 \\
0.02 \\
1.0\end{array}$ & 0 & 0 & $\begin{array}{l}1.7 \\
1 \\
0.02 \\
1.0\end{array}$ & $\begin{array}{l}1.5 \\
1 \\
0.02 \\
1.0\end{array}$ & 0 & 0 & $\begin{array}{l}0.5 \\
1 \\
0.005 \\
1.0\end{array}$ \\
\hline Argulus foliaceus & $\begin{array}{l}\mathrm{PR} \\
\mathrm{IR} \\
\mathrm{AB} \\
\mathrm{MI}\end{array}$ & 0 & $\begin{array}{l}1.1 \\
1 \\
0.01 \\
1.0\end{array}$ & 0 & 0 & $\begin{array}{l}0.7 \\
1 \\
0.01 \\
1.0\end{array}$ & 0 & 0 & $\begin{array}{l}0.8 \\
1 \\
0.01 \\
1.0\end{array}$ & 0 & 0 & $\begin{array}{l}0.26 \\
1 \\
0.003 \\
1.0\end{array}$ \\
\hline
\end{tabular}

PR - prevalence

IR - intensity range

$\mathrm{AB}$ - abundance

MI - mean intensity

* - based on "raw" data 
intensities in the river mouth and the lake $(1-16)$. The overall abundance and mean intensity were 0.67 and 2.95 respectively. Those parameters were highest in 1985 ( $0.56 \& 4.19)$ and lowest in 1987 ( $0.37 \& 1.6)$. The maximal values occurred for summers $(0.75 \& 3.52)$ and for fish from the lagoon $(0.98 \& 3.74)$.

Caligus lacustris Steenstrup \& Lütken, 1861 (Copepoda, Siphonostomatoida, Caligidae)

Only two individuals occurred on the fish studied. They were found in the fall of 1988 one on each two fish from the lagoon.

Argulus foliaceus (Linne, 1758) (Branchiura, Argulidae)

The only individuals was found in the spring of 1986 , on a fish from the lagoon.

Crustacean parasites of bream (Abramis brama): (Table 3)

Ergasilus sieboldi von Nordmann, 1832 (Copepoda, Poecilostomatoida, Ergasilidae)

A total of 652 individuals was recovered from the 370 hosts studied. They occurred each year in every season studied, and in all three localities. The overall prevalence (for the whole survey) was: $48.1 \%$, but it varied from $33 \%$ in 1985 to $61.1 \%$ in 1986 . The prevalence in the springs was low (33.1\%), increasing in the falls (56.7\%). $E$. sieboldi was less prevalent in the lake (28.3\%) than in the river mouth $(48.5 \%)$, or the lagoon (67.5\%). The widest intensity range was 1-23 (in 1986 and in the summers). The narrowest intensity range was 1-9 (1988) and 1-8 (the springs). The highest intensities occurred in the lagoon (1-23); the lowest intensities in the lake $(1-8)$. The overall abundance and mean intensity were 1.76 and 3.56 respectively. Those parameters were highest in 1986 ( $3.5 \& 5.73$ ). The maximal values occurred for summers (2.33 \& 4.18) and for fish from the lagoon (2.96 \& 4.38).

Tracheliastes maculatus Kollar, 1835 (Copepoda, Siphonostomatoida, Lernaeopodidae)

A total of 65 individuals was recovered from the 370 hosts studied. They occurred each year, in every season studied, and in all three localities. The overall prevalence (for the whole survey) was: $9.7 \%$, but it varied from $9 \%$ in 1985 to $11.1 \%$ in 1988 . The highest prevalence occured in the summers (14.2\%). T. maculatus was less prevalent in the river mouth $(7.7 \%)$ than in the lagoon $(9.2 \%)$, or the lake $(12.5 \%)$. The widest intensity range was 1-6 (in 1985 and in the summers). The narrowest intensity range was 1-3 (in 1986 and in the falls). The highest intensities occurred in the lake (1-6); the lowest intensities in the lagoon (1-3). The overall abundance and mean intensity 
Table 3

Parmeters of infection of breana, within 1985-1988

\begin{tabular}{|c|c|c|c|c|c|c|c|c|c|c|c|c|}
\hline Parasite species & $\begin{array}{l}\text { Invasion } \\
\text { para- } \\
\text { meters }\end{array}$ & 1985 & 1986 & 1987 & 1988 & Spring & Summer & $\begin{array}{l}\text { River } \\
\text { mouth }\end{array}$ & Lake & Overall" & F@ll & Lagoon \\
\hline Ergasilus sieboldi & $\begin{array}{l}\mathrm{PR} \\
\mathrm{IR} \\
\mathrm{AB} \\
\mathrm{MI}\end{array}$ & $\begin{array}{l}33.0 \\
1-14 \\
0.85 \\
2.58\end{array}$ & $\begin{array}{l}61.1 \\
1-23 \\
3.5 \\
5.73\end{array}$ & $\begin{array}{l}44.4 \\
1-14 \\
1.38 \\
3.1\end{array}$ & $\begin{array}{l}55.6 \\
1-9 \\
1.42 \\
2.56\end{array}$ & $\begin{array}{l}33.1 \\
1-8 \\
0.72 \\
2.19\end{array}$ & $\begin{array}{l}55.8 \\
1-23 \\
2.33 \\
4.18\end{array}$ & $\begin{array}{l}48.5 \\
1-14 \\
2.78 \\
3.67\end{array}$ & $\begin{array}{l}28.3 \\
1-8 \\
0.55 \\
1.94\end{array}$ & $\begin{array}{l}48.1 \\
1-23 \\
1.76 \\
3.56\end{array}$ & $\begin{array}{l}56.7 \\
1-17 \\
2.32 \\
4.09\end{array}$ & $\begin{array}{l}67.5 \\
1-23 \\
2.96 \\
4.38\end{array}$ \\
\hline Tracheliastes maculatus & $\begin{array}{l}\text { PR } \\
\text { IR } \\
\text { AB } \\
\text { MI }\end{array}$ & $\begin{array}{l}9.0 \\
1-6 \\
0.17 \\
1.89\end{array}$ & $\begin{array}{l}10.0 \\
1-3 \\
0.16 \\
1.56\end{array}$ & $\begin{array}{l}8.9 \\
1-4 \\
0.16 \\
1.75\end{array}$ & $\begin{array}{l}11.1 \\
1-5 \\
0.22 \\
2.0\end{array}$ & $\begin{array}{l}8.5 \\
1-5 \\
0.16 \\
1.91\end{array}$ & $\begin{array}{l}14.2 \\
1-6 \\
0.27 \\
1.88\end{array}$ & $\begin{array}{l}7.7 \\
1-4 \\
0.11 \\
1.4\end{array}$ & $\begin{array}{l}12.5 \\
1=6 \\
0.26 \\
2.07\end{array}$ & $\begin{array}{l}9.7 \\
1-6 \\
0.18 \\
1.8\end{array}$ & $\begin{array}{l}6.7 \\
1-3 \\
0.1 i \\
1.5\end{array}$ & $\begin{array}{l}9.2 \\
1-3 \\
0.17 \\
1.82\end{array}$ \\
\hline Argulus foliaceus & $\begin{array}{l}\text { PR } \\
\text { IR } \\
\text { AB } \\
\text { MI }\end{array}$ & 0 & 0 & $\begin{array}{l}1.1 \\
1 \\
0.01 \\
1.0\end{array}$ & $\begin{array}{l}3.3 \\
1 \\
0.03 \\
1.0\end{array}$ & $\begin{array}{l}1.5 \\
1 \\
0.01 \\
1.0\end{array}$ & $\begin{array}{l}0.8 \\
1 \\
0.01 \\
1.0\end{array}$ & 0 & $\begin{array}{l}2.5 \\
1 \\
0.03 \\
1.0\end{array}$ & $\begin{array}{l}1.1 \\
1 \\
0.01 \\
1.0\end{array}$ & $\begin{array}{l}0.8 \\
1 \\
0.01 \\
1.0\end{array}$ & $\begin{array}{l}0.8 \\
1 \\
0.01 \\
1.0\end{array}$ \\
\hline Coligus lacustris. & $\begin{array}{l}\text { PR } \\
\text { IR } \\
\text { AB } \\
\text { MI }\end{array}$ & 0 & $\begin{array}{l}1.1 \\
1 \\
0.01 \\
1.0\end{array}$ & $\begin{array}{l}1.1 \\
1 \\
0.01 \\
1.0\end{array}$ & 0 & 0 & $\begin{array}{l}1.7 \\
1 \\
0.02 \\
1.0\end{array}$ & 0 & 0 & $\begin{array}{l}0.5 \\
1 \\
0.005 \\
1.0\end{array}$ & 0 & $\begin{array}{l}1.7 \\
1 \\
0.02 \\
1.0\end{array}$ \\
\hline
\end{tabular}


were 0.18 and 1.8 , respectively. Those parameters were highest in $1988(0.22$ \& 2.0$)$. The maximal values occurred for summers $(0.27 \& 1.88)$ and for the fish from the lake (0.26 \& 2.07).

Some of the parasites were found to cause deep skin lesions, involving perforation of the scale, being the attachment place of the females copepods.

Argulus foliaceus (Linne, 1758) (Branchiura, Argulidae)

Only four individuals were found. They occurred in all seasons studied, but only in 1987 and 1988, and only in the samples from the lagoon and the river mouth. The overall prevalence was $1.1 \%$.

Caligus lacustris Steenstrup \& Lůtken, 1861 (Copepoda, Siphonostomatoida, Caligidae)

Only two individuals were found. They occurred in summer samples of 1986 and 1987, taken from the lagoon. The overall prevalence was $0.5 \%$.

\section{Crustacean parasites of pilke-perch (Stizostedion lucioperca): (Table 4)}

Achtheres percarum von Nordmann, 1832 (Copepoda, Siphonostomatoida, Lernaeopodidae)

A total of 8691 individuals was recovered from the 433 hosts studied. They occurred each year, in every season studied, and in all three localities. The overall prevalence (for the whole survey) was $93.5 \%$, having grown constantly from $81.5 \%$ in 1984 to $100 \%$ in 1988. It was highest in the summers $(97.5 \%)$. A. percarum was less prevalent in the lagoon (90\%) than in the lake $(93.2 \%)$ or in the river mouth $(97.3 \%)$. The widest intensity range was in the falls (1-117) and in 1988 (2-117). The narrowest intensity range was in 1985 (1-57), and in the summers (1-62). There were no major differences between studied areas in this respect. The overall abundance and mean intensity were similar: 20.07 and 21.16, respectively. Those parameters were highest in 1988 (33.7 \& 33.7) and lowest in 1985 (12.1 \& 13.1). The maximal values occurred in the falls (23.95 \& 25.42), in fish from the river mouth (22.24 \& 22.86), and in those from the lake (20.73 \& 22.25).

The parasites occurred mostly on gill arches and in the mouth cavity. Some adult females were found on gill filaments. Some of them caused necrotic lesions of parts below the attachment sites, as well as epithelial hyperthrophy. Chalimus larvae were found mostly on the filament tips and occasionally on the opercula. 
Table 4

Parameters of infection of pike-perch, within 1984-1988

\begin{tabular}{|c|c|c|c|c|c|c|c|c|c|c|c|c|c|}
\hline Parasite species & $\begin{array}{c}\text { Invasion } \\
\text { para- } \\
\text { meters }\end{array}$ & 1984 & 1985 & 1986 & 1987 & 1988 & Spring & Summer & Fall & Lagoon & $\begin{array}{l}\text { River } \\
\text { mouth }\end{array}$ & Lake & Overall " \\
\hline $\begin{array}{l}\text { Achtheres } \\
\text { percarum }\end{array}$ & $\begin{array}{l}\text { PR } \\
\text { IR } \\
\text { AB } \\
\text { MI }\end{array}$ & $\begin{array}{l}81.5 \\
1-84 \\
15.6 \\
19.2\end{array}$ & $\begin{array}{l}92.6 \\
1-57 \\
12.1 \\
13.1\end{array}$ & $\begin{array}{l}97.8 \\
2-79 \\
18.5 \\
18.9\end{array}$ & $\begin{array}{l}98.9 \\
1-113 \\
22.1 \\
22.4\end{array}$ & $\begin{array}{l}100 \\
2-117 \\
33.7 \\
33.7\end{array}$ & $\begin{array}{l}89.3 \\
1-87 \\
16.5 \\
18.5\end{array}$ & $\begin{array}{l}97.5 \\
1-62 \\
18.7 \\
19.2\end{array}$ & $\begin{array}{l}94.2 \\
1-117 \\
23.95 \\
25.42\end{array}$ & $\begin{array}{l}90.0 \\
1-57 \\
17.11 \\
19.02\end{array}$ & $\begin{array}{l}97.3 \\
1-117 \\
22.24 \\
22.86\end{array}$ & $\begin{array}{l}93.2 \\
1-113 \\
20.73 \\
22.25\end{array}$ & $\begin{array}{l}93.53 \\
1-117 \\
20.07 \\
21.16\end{array}$ \\
\hline $\begin{array}{l}\text { Ergasilus } \\
\text { sieboldi }\end{array}$ & $\begin{array}{l}\text { PR } \\
\text { IR } \\
A B \\
M I\end{array}$ & $\begin{array}{l}37.0 \\
1-4 \\
0.61 \\
1.65\end{array}$ & $\begin{array}{l}14.9 \\
1-3 \\
0.2 \\
1.36\end{array}$ & $\begin{array}{l}47.2 \\
1-12 \\
1.45 \\
3.10\end{array}$ & $\begin{array}{l}22.2 \\
1-6 \\
0.4 \\
1.8\end{array}$ & $\begin{array}{l}37.8 \\
1-4 \\
0.73 \\
1.94\end{array}$ & $\begin{array}{l}12.9 \\
1-3 \\
0.19 \\
1.44\end{array}$ & $\begin{array}{l}29.2 \\
1-8 \\
0.54 \\
1.86\end{array}$ & $\begin{array}{l}46.8 \\
1-12 \\
1.13 \\
2.41\end{array}$ & $\begin{array}{l}32.1 \\
1-10 \\
0.67 \\
2.09\end{array}$ & $\begin{array}{l}33.3 \\
1-12 \\
0.93 \\
2.8\end{array}$ & $\begin{array}{l}27.4 \\
1-3 \\
0.38 \\
1.38\end{array}$ & $\begin{array}{l}30.95 \\
1-12 \\
0.66 \\
2.13\end{array}$ \\
\hline $\begin{array}{l}\text { Argulus } \\
\text { foliaceus }\end{array}$ & $\begin{array}{l}\text { PR } \\
\text { IR } \\
A B \\
\text { MI }\end{array}$ & $\begin{array}{l}3.7 \\
1 \\
0.04 \\
1.0\end{array}$ & $\begin{array}{l}3.6 \\
1 \\
0.04 \\
1.0\end{array}$ & $\begin{array}{l}3.4 \\
1 \\
0.03 \\
1.0\end{array}$ & 0 & $\begin{array}{l}4.4 \\
1 \\
0.04 \\
1.0\end{array}$ & $\begin{array}{l}3.6 \\
1 \\
0.04 \\
1.0\end{array}$ & $\begin{array}{l}4.2 \\
1 \\
0.04 \\
1.0\end{array}$ & $\begin{array}{l}1.7 \\
1 \\
0.02 \\
1.0\end{array}$ & $\begin{array}{l}1.4 \\
1 \\
0.01 \\
1.0\end{array}$ & $\begin{array}{l}2.0 \\
1 \\
0.02 \\
1.0\end{array}$ & $\begin{array}{l}5.5 \\
1 \\
0.05 \\
1.0\end{array}$ & $\begin{array}{l}3.0 \\
1 \\
0.03 \\
1.0\end{array}$ \\
\hline $\begin{array}{l}\text { Caligus } \\
\text { locustris }\end{array}$ & $\begin{array}{l}\text { PR } \\
\text { IR } \\
\mathrm{AB} \\
\mathrm{MI}\end{array}$ & 0 & 0 & $\begin{array}{l}4.5 \\
1-2 \\
0.06 \\
1.25\end{array}$ & $\begin{array}{l}6.7 \\
1-4 \\
0.1 \\
1.5\end{array}$ & $\begin{array}{l}4.4 \\
1 \\
0.04 \\
1.0\end{array}$ & $\begin{array}{l}2.1 \\
1 \\
0.02 \\
1.0\end{array}$ & $\begin{array}{l}5.0 \\
1-4 \\
0.08 \\
1.5\end{array}$ & $\begin{array}{l}2.9 \\
1-2 \\
0.03 \\
1.2\end{array}$ & $\begin{array}{l}8.6 \\
1=4 \\
0.11 \\
1.33\end{array}$ & $\begin{array}{l}1.4 \\
1 \\
0.01 \\
1\end{array}$ & 0 & $\begin{array}{l}3.23 \\
1-4 \\
0.04 \\
1.29\end{array}$ \\
\hline
\end{tabular}


Ergasilus sieboldi von Nordmann, 1832 (Copepoda, Poecilostomatoida, Ergasilidae)

A total of 286 individuals was recovered from the 433 hosts studied. They occurred each year, in every season studied, and in all three localities. The overall prevalence (for the whole survey) was: $30.95 \%$, but it varied from $14.9 \%$ in 1985 to $47.2 \%$ in 1986 . The prevalence in the springs was low (12.9\%) increasing in the falls (46.8\%). E. sieboldi was less prevalent in the lake (27.4\%) than in the river mouth (33.3\%). The widest intensity range was 1-12 (in 1986 and in the falls). The narrowest intensity range was 1-3 (in 1985 and in the springs). The greatest intensities occurred in the river mouth $(1-12)$ and the lagoon (1-10); the lowest intensities in the lake (1-3). The overall abundance and mean intensity were 0.66 and 2.13 respectively. Those parameters were highest in 1986 (1.45 \& 3.1) and lowest in 1985 ( $0.2 \& 1.36)$. The maximal values occurred in the falls $(1.13 \& 2.41)$ and in the fish from the river mouth $(0.93 \& 2.8)$.

Argulus foliaceus (Linne, 1758) (Branchiura, Argulidae)

A total of 13 individuals was recovered from the 433 hosts studied. They occurred each year (except for 1987), in every season studied, and in all three localities. The overall prevalence, calculated for all fish studied in the whole survey, was $3.0 \%$, but it varied from $3.4 \%$ in 1986 to $4.4 \%$ in 1988 . The majority of A. foliaceus was found in the lake. The infection intensity was 1 in all findings.

Caligus lacustris Steenstrup \& Lütken, 1861 (Copepoda, Siphonostomatoida, Caligidae)

A total of 18 individuals was found. They occurred in all seasons studied in 1986, 1987 and 1988, but in the samples from the lagoon and the river mouth only. The overall prevalence was $3.23 \%$ and the overall intensity range was 1-4.

\section{DISCUSSION}

The infection parameters for the five parasites found in the three fishes studied varied essentially. The specificity of Achtheres percarum and Tracheliastes maculatus was confined to one host only, while Ergasilus sieboldi, Caligus lacustris and Argulus foliaceus occured in the three host species.

Achtheres percarum exhibits the highest infection rate among the parasites found. With a prevalence reaching $100 \%$ and intensity exceding 100 in certain cases, this parasite seems to be really important for the fish health. Several infected pike-perch showed signs of pathological changes induced by the parasite. The high infection rate continued throughout the years being monitored and in the three localities. 
According to Kozikowska (1957), the infection was moderate in 1954-1955 and reached $21.8 \%$ only for the lagoon;

Tracheliastes maculatus is a specific parasite of bream and infected relatively low numbers of its hosts $(9.7 \%)$. In the past, the parasite was found more frequently in this area:Kozikowska (1957)found it on $25.9 \%$ of 85 bream from the lagoon; Wierzbicka (1978) found it on $30.0 \%$ of the 233 bream from the lake.

Ergasilus sieboldi turned out to be the most common crustacean parasite in the area studied. It was moderately prevalent, but it showed low intensity and abundance. It occurred more frequently on bream (48.1\%) than on pike-perch $(31.0 \%)$ or on roach (22.2\%). In all three hosts the prevalence grew from spring to fall, and it was less prevalent in the lake, than in the lagoon. In the past, $E$. sieboldi was recorded by Kozikowska (1957) who recovered the copepod from $9.4 \%$ of the 85 bream she examined, but she did not find any on the 38 roach and 238 pike-perch she examined. Wierzbicka (1978) found the copepod in $41.2 \%$ of the 233 bream from the lake. She also found that seasonal occurrence of the parasite, from 1969 to 1971, was variable.

Caligus lacustris, despite of its occurrence in the three host species studied, turned out to be rare. Its infection parameters were very low in bream and roach and only slightly higher in pike-perch. According to Kozikowska (1957), the parasite occured on 1.7\% of the latter fish in 1954-1955. It did not occure at all on bream from the lake in 1969-1971 (Wierzbicka, 1978).

Argulus foliaceus, as Caligus lacustris, may be considered a rare parasite of its hosts. It was not recorded by Kozikowska (1957) and Wierzbicka (1978) found it on only $1.7 \%$ of the bream she studied.

It is difficult to discuss long term changes in infection by crustacean parasites in the area studied, basically due to the lack of sufficient data. The only reliable conclusion might regard invasion Achtheres percarum, populations of which have increased greatly in the past thirty years. The high prevalence, combined with the pathogenic impact of the parasite and summer oxygen deficiencies, may be lethal to pike-perch in the Szczecin Lagoon and in the whole estuary area.

\section{ACKNOWLEDGEMENTS}

The present study was a part of the long-term project contracted and financed by the authorities of the Szczecin District (Urząd Wojewódzki w Szczecinie).

The present author is indebted to Prof. Dr. M.D.B. Burt of the Depertment of Biology of the University of New Brunswick, Fredericton, N.B. for reviewing the manuscript. 


\section{REFERENCES}

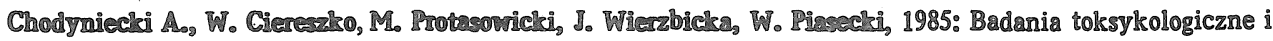
parazytologiczne, in: Drzycimski Io (supervisor): Badania nad stopniem zanieczyszczenia Zalewu Szczecinskiego przez aglomeracje szczecin̊sks i wody ujşciowe Odry ze szczegölnym uwzglednieniem Zakìadow Chemicznych „Police”。Akademia Rolnicza w Szczecinie, Instytut Oceanografii Rybackiej i Ochrony Morza (maszynopis), pp: 34-43.

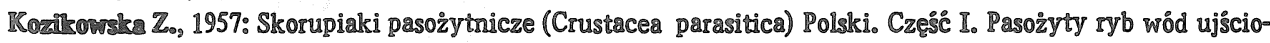
wych Odry. - Zool. Polon. \& (2-3): 217-270.

Piacecki Wo, 1989: Parazytologia. In: Drzycirnski, I. (supervisor): Okreslenie stopnia zanieczyszczenia Zalewu Szczecinoskiego przez aglomeracje szczecinsską i wody ujs̄ciowe Odry ze szczego̊lnym uwzgleddnieniem Zaktadôw Chemicznych „Police”. - Akademia Rolnicza w Szczecinie, Instytut Oceanografii Rybackiej i Ochrony Morza (maszynopis), ppo: 95-105.

Wilersbick Jo, 1978: Cestoda, Nematoda, Acanthocephala, Hirudinea and Crustacea from Abramis brama, A. ballerus and Blicce bjoercno of the Dabie lake, Poland. - Acta Parasitol. Polon. 25 (36): 293-305.

Wierzbick Jo Wo Piasecki, 1987: Parazytologia. In: Drzycimski, I. (supervisor): Okresilenie stopnia zanieczyszczenia Zalewu Szczeciñskiego przez aglomeracje szczecinsksą i wody ujs̄ciowe Odry ze szczego̊lnym uwzglednieniem Zakiadow Chemicznych „Police”。 - Akademia Rolnicza w Szczecinie, Instytut Oceanografii Rybackiej i Ochrony Morza (maszynopis), pp: 63 -70 .

Wojciech PIASECKI

\section{PASOZ̊YTNICZE SKORUPIAKI TRZECH GATUNKO゚W RYB Z WÓD UJS̊CIOWYCH RZEKI ODRY, POLSKA}

\section{STRESZCZENIE}

Badano trzy gatunki ryb, mających znaczenie gospodarcze, pod kątem obecnošci pasożytniczych skorupiakơw. W latach 1985-1988 zbadano 387 płoci (Rutilus rutilus) oraz 370 leszczy (Abramis brama).W pierwszej $z$ wymienionych ryb znaleziono trzy gatunki pasożytoow, w drugiej zas cztery. W latach 1984-1988 przebadano w ten sam sposöb 433 sandacze. Znaleziono w nich cztery gatunki skorupiakoiw. Dla wszystkich pasożyto̊w, dla każdego żywiciela $z$ osobna wyliczono podstawowe parametry zarażenia (ekstensywnošc, intensywnos̊c, s̊rednią intensywnos̊c zarażenia populacji oraz s̊rednią intensywnošc zarażenia). Zwrōcono uwage na sezonowe różnice w występowaniu pasożytów, jak też na ro̊żnice między trzema badanymi rejonami.

Author's address:

Received: 1992.04 .10

Dr. Wojciech Piasecki

University of Agriculture in Szczecin

Zakład Chorób Ryb

ul. Kazimierza Krölewicza 4

Polska (Poland) 